\title{
Sobre el Humanismo catalán y las periodizaciones
}

\author{
JuLIA BUTINÁ \\ (UNED)
}

Alrededor del Humanismo han abundado las disputas científicas ${ }^{1}$; entre ellas se halla la relativa al hecho de si debe incluirse la producción en las lenguas vulgares. Aquí partiremos de posturas de síntesis ${ }^{2}$-que han ido superando aspectos como éste, aún discutidos sin embargo-, a la luz de estudios generales y recientes de nuestro ámbito hispánico que han propuesto un nuevo orden acerca del concepto y van a servirnos de referente (González Rolán... 2002), o bien que recogen las líneas actuales de investigación teórica sobre periodizaciones (Gutiérrez Carbajo 2002).

1 Discusiones que tienen precedentes ilustres en los primeros humanistas (Gonzalez Rolán-Saquero-Lopez Fonseca 2002, 61; en adelante González Rolán... 2002).

2 Es conocida la del profesor Batllori, que, como historiador de la cultura, ve una salida entre la concepción rupturista y la continuista en las reflexiones de Cassirer, Garin, Kristeller o Maravall, y, en cuanto a las lenguas, podriamos antadir a Kraye. Concibe aquel investigador una fractura pero no total, entendiendo el Humanismo no como un proceso exclusivamente filológico sino como una actitud de algunos pensadores que, en el transito del siglo XIV al XV, comparten una 6ptica antropocéntrica; integra también latín y lengua vulgar, asf como subraya el origen italiano del movimiento (J. Solervicens en VV AA 2001, 91). Por otro lado, en cuanto a la tradición catalana, remito a A. Rubio, quien inclufa ya lo producido en las diversas lenguas (J. Rubio 1992, 92).

En González Rolán... 2002 se adopta asimismo un sentido amplio desde la tradición clásica, que se entiende como "la recepción del legado clásico tanto en vernáculo como en latin, como sucedió durante el Medievo y el Renacimiento", 40, y se aboca al concepto lato de Humanismo filologico-literario (ib., 61-62), como veremos más adelante; la variación de lenguas es lo que distinguirfa la modalidad -interlinguística o intralinguística - de propagarse aquella tradición. Cabe comentar aún que la recopilación de pareceres del coloquio Di fronte al classici (Dionigi 2001) ratifica por lo general esta idea de gene- 
No me centro en el Humanismo hispánico porque estamos lejos de dominar el panorama en el que -como manifiestan las I Converses Filologiques - hay muchos puntos de estudio aún abiertos. Ahora bien, dado que respecto a los humanistas italianos como motores del movimiento en las dos Coronas ocurrió lo mismo aunque de distinta manera -es decir que se pueden distinguir los rasgos en que aquellos humanistas difieren o se asemejan-, me permitire efectuar algunas abstracciones. Si bien me emplazo con preferencia en el llamado Humanismo catalán - catalanoaragones, evidentemente-, muy a pesar de que el siglo $\mathrm{XX}$ ha dejado un difícil tratamiento del tema, puesto que estos estudios han trazado un curso irregular, desde la exaltación a la negación del concepto. Aquí nos situamos en el reconocimiento del mismo, dentro de la mencionada visión panorámica hispanista en construcción.

En resumen anticipado cabe decir que, frente a la tradición de los estudios de Filologia Catalana que ha mantenido el concepto (n. 13 infra), se ha planteado un fuerte revisionismo en los dos últimos decenios, derivado principalmente de un trabajo de Lola Badia de 1980 (recogido en 1988, 13-38) secundado por la mayor parte de la crítica ${ }^{3}$.

rosa amplitud y desde el principio se resuelve all que «L'Europa ha il volto della pluralita; $e$ il latino $e$ il segno linguistico unitario di tale pluralita», 10; hoy, también, más que nunca quizás, la cultura occidental intenta conciliar dos extremos, lo particular y lo universal: «Siempre la aparente aporfa entre universalidad y particularismo, que es la esencia misma de Europa», M. Batllori en la primera conmemoración del Día de Europa en Catalufía, 1982, recogido en la editorial del segundo volumen monográfico batlloriano *Anthropos. Revista de documentación cientffica de la cultura» 112, 9-10.

3 L. Badia es tajante en 1996: El terme «Humanisme» no defineix la cultura literdria dels nostres escriptors en vulgar dels segles XIV $i X V$, «L'Avenç» 200,20-23; afirmación a la que se contrapone Vilallonga afirmando su valor para los que escriben en latín $(2001,487, n$. 24). En cuanto a la muy general aceptación del revisionismo, baste como dato elocuente la reciente alusión al hecho como si fuera un axioma: «Ara sabem que l'etiqueta 'és una maniobra noucentista, un típic producte de la necessitat de retrobar una historia nacional de Catalunya que estigui d'acord amb un determinat ideal' (Badia 1988, 43)... Comprovem tambe que l'edifici arquitectonic construik per a encabir ideologicament $i$ literaria les figures clau del pas del segie XIV al XV ha estat sempre una realitat virtual o, si voleu, un producte logic de la forma d'entendre un perfode cultural en una determinada epocan (Martinez Romero 2002, 28-29, quien recoge esa cita de Badia). La opinión es tan generalizada que, si es criticable que una visión al unisono pueda llegar a desfigurar los hechos o convertirse en militante, eso es lo que puede ocurrir en la actualided con la ides tan común del ketiquetaje* (más recientemente tambien la recogemos en $\mathbf{M}$. Garcia Sempere, Sobre la diversitat de manifestacions literdries en la segona meitat del segle XV: contactes entre les obres $i$ els autors, «Caplletra*34, 2003, 55-78), ya que se llega a ignorar la opinión contraria. Incluso se ha llegado a vislumbrar intencionalidades espureas bajo la categoria o calificación humanista para las obras catalanas de esta Epoca: "son manies (entendridores manies) dels historiadors políticament interessats de la nostra cultura" (Jordi Galves, De quan Bernat Metge feia conya pel Born $i$ somniava en divendres, *Quadern» 5 de *El País*, 26 septiembre 2002; texto que procede del campo periodístico, pero que refleja el clímax reinante derivado del parecer de los estudiosos (Badia 1988, 49; 1996, 21, 22). Sin embargo, podrfan oponerse - al margen de los resultados, que no conozco - hechos como la Jornada de estudio, celebrada en marzo de 2003 en la Universidad de Barcelona, sobre los maestros de la Filologia Catalana y la Filologfa Clásica de los perfodos romintico y novecentista en Cataluna (Antoni Bergnes de las Casas, Manuel Mila i Fontanals, Josep Balari, Antoni Rubió i Lluch, Luifs Segala, Pompeu Fabra, Joaquim Balcells y Jondi Rubió i Balaguer). 
Entre las últimas referencias a este movimiento se hallan las de Mariángela Vilallonga, que -como suele ocurrir desde la perspectiva de la Filología Clásica - quitan hierro a la aversión que se constataba, a causa de la tendencia revisionista, a considerar el término ni siquiera apto para el uso ${ }^{4}$; pero opina a la vez que, dado que aquella producción se escribió mayoritariamente en latín, «la presa de posició a favor de l'expressió llatina i de la imitació dels autors llatins per part de qualsevol que es vulgui dedicar a escriure, amb ambició estètica, és clar, ... és el primer pas per formar part del que anomenem humanisme catalas (Vilallonga $2001,479)^{5}$. De aquí parece que se podría desprender que no hay que entender bajo la aspiración estética obras como Lo somni o el Curial, aunque practiquen la imitatio bajo el nuevo espiritu ennoblecedor al abrigo de la lengua y literatura latinas; no esquivaremos el tratar de este punto, pero nos permitimos obviarlo inicialmente pues hemos dicho que partimos de la misma denominación de humanistas para las obras escritas en vulgar - con evidente ambición literaria y renovadora, así como con uso imitativo del latín o de los autores latinos - que para las latinas, de acuerdo con aquellos trabajos en los que apoyamos este nuestro.

Para una información o resumèn de la situación, desde el punto de vista de los contenidos, hay que acudir al artículo de Puig i Oliver Humanisme catald?, donde - hace ya más de 10 años $^{6}$ - se apuntaban estas premisas para avalar el 487.

4 «podem parlar sense complexos d'humanisme a Catalunya, Mallorca i Valencian, Vilallonga 2001,

3 En cuanto a la elección de la expresión latina como signo del ideario humanista, véase la n. 2 supra. Vilallonga avala sus juicios sobre esta producción en latín en el repertorio bio-bibliográfico $L a$ literatura llatina a Catalunya al segle XV, Publicaciones de la Abadía de Montserrat 1993, donde reúne a 64 autores. Esta latinista, por otro lado, alude a un obstáculo digno de ser destacado y al que abocaremos desde distintos ángulos: la parcelación actual de los conocimientos. $k E l$ que resulta evident És que es produeix un tall per la quiestió de la llengua i per la mateixa naturalesa dels estudis universitaris actuals. Hi ha qui es dedica a estudiar la filologia llatina i qui es dedica a estudiar la filologia catalana. Per molt que creiem que podrem unir aquests móns introduint materies dedicades a explicar la historia de la cultura, al final l'especialització excessiva, hereva encara, i potser cada vegada més, de l'escolàstica, s'imposa en un món, el d'avui, que ens desborda d'informació. Així, resulta molt més facil estudiar els autors que van escriure en llati dins de la filologia llatina i anomenar la seva produccio literària literatura neollatina, sigui del segle XV o del segle XIX, i estudiar els autors que van escriure en catala dins de la filologia catalana i deixar-nos de noms tan carregats de connotacions diverses com humanisme o humanista. Però no te molt mes interès, malgrat les dificultats dbvies, intentar mostrar la profunda connexió entre uns i aitres, basada més en el seu ideari i en la seva actitud davant la vida, que comença justament en la tria d'un model de llengua per expressar-se? $x$, Vilallonga 2001, 487.

Cabe anotar que la critica a la parcelación la recoge también González Rolán... 2002, 38-39, a traves de Curtius, mostrando que para el dibujo de la literatura curopea se requiere el estudio de la Filologfa Clasica, la medieval y las modernas; también, que Batllori calificaba a aquella de kbalcanización» o que su condena se percibe en distintos ámbitos (Santiago Grisolía advierte la que se da entre ciencia y cultura, *El Palsw, 27 abril 2003, 56). Eulalia Duran aflade otras dificultades para los estudiosos del movimiento, pues «Els historiadors que han abordat aquest periode son fills de llur ¿poca i, per tant, sintonitzen millor amb aquelles caracteristiques que els son més familiars. El Romanticisme connecth amb l'Bdat Mitjana... El Noucentisme tendí a revalorar l'Humaniame i el Renaixementw (prologo a Batllori 1995, VII).

6 Para una mise au point de la polémica anterior, vease L. Badia 1980, 69-70. 
reconocimiento del mismo en su puridad en las letras catalanas en el paso del siglo XIV al XV: que se detectase un interes por la Antiguiedad que tendiese a suplantar los valores intelectuales y morales transmitidos por la tradición medieval cristiana y que apareciese algún rasgo que revelase una conexión con alguna de las nuevas direcciones literarias impulsadas por Petrarca, especialmente con alusión a «l'emergència de l'individu humà al primer pla de les preocupacions intel-lectuals, aspecte negligit en la discussio en curs sobre l'humanisme català" $(1991,297)$. Así, se fijaban estos dos grandes condicionantes.

Y bien: los dos libros que he publicado en 2002 , Del «Griselda» catald al castelld y En los origenes del Humanismo: Bernat Metge, a mi entender, dan cumplida respuesta desde la Filología a aquellos requisitos que a modo de preguntas se formulaban desde la Filosofía para las letras catalanas ${ }^{7}$. Desde el inicio del diálogo Lo somni, Metge, por medio de una apertura dialogante hacia las tradiciones en busca de la objetividad y en aras de un sincretismo - desde una posición de desdoblamiento íntimo y de introspección, con influencia luliana y agustiniana -, se aleja del más leve rastro de una mentalidad vieja; es más, efectúa una metódica filtración de acuerdo con la vigencia de la racionalidad y la burla de los moldes caducos. Aunque escribe en un entorno social no sólo acentuadamente tradicional sino en un momento de peligrosidad ${ }^{8}$, no reniega de su filiación humanista, lo cual le

7 Más allá, sin embargo, de Bernat Metge, también considero válido a estos efectos el Curial, según el enfoque que presente en Tras los origenes del humanismo: $E l$ «Curial e Guelfa». La presencia clasicista, la superficial y la profunda - de la Eneida a la Ética Nicomáquea-, propicia nuevos modelos y virtudes; por otro lado, toda la obra afluye al Somnium Scipionis (véase el hipotexto propuesto en Butiná 2001, 451).

En cuanto al rastreo petranquesco que marca Puig i Oliver, tanto el autor de una como de la otra obra, saben bien lo que supuso su renovación, pues lo imitan -e incluso corrigen - a su aire, haciéndolo suyo. Al valor del yo, sin embargo, es más sensible Metge, como se hace patente ya desde 1381, en el Libre de Fortuna e Prudencia (Butiná 2003 b), y, más aún, en el Griselda (Butifía 2002 b), donde se enmarca el texto con dos cartas, al estilo de las cornisas decameronianas pero sobre todo a imitación de Petrarca; estas epistolas están escritas por un yo estridente y en franca oposición a un interlocutor, que sólo se percibe a la luz de su fuente: las cartas seniles del Griseldis.

- El malestar social, que explotó a la muerte del rey Juan I -amigo suyo y conocido como kel Humanista», «El Amador de la Gentileza», «El Cazador o «El Despreocupado», con cuyo espiritu dialoga en Lo somni - , ha sido recientemente comparado al de un golpe de estado debido a las tensiones sociales y políticas que acarrearon delaciones, procesos, etc., en los que influirfan líneas personalistas y de poder ideol6gico, faltos de asepsia u objetividad (J. Rebagliato i Font 1999, 63-67; tambión puede verse Butiñá 2002 a, 175-181). Metge sufrí6 las consecuencias de perder a su protector y se vio obligado a esconder su ideologia artisticamente, al margen de que el estilo culturalista y recoveco estuviera de moda; pero, incluso en medio de acusaciones deleznables y de un alto riesgo, supo mantener su independencia y libertad - como bien garantiza una tan fina como firme red de burlas e ironias - , cosa que posteriormente no conseguirfan muchos humanistas, ya que abundan las obras panegfricas por encima de las comprometidas o de denuncia moral. 
convierte en un aventajado freelance o en un ejemplar acentuadamente solo9. Por la fecha de su obra, Metge se ha de vincular al humanismo florentino' ${ }^{10}$, considerado por lo general como el más genuino, a pesar del lastre medievalizante que inevitablemente transportaba.

Pero Metge, a pesar de la fuerte admiración que profesa a Petrarca, condena su moral por misógina como medievalizante, en virtud de autores clásicos: Ovidio, Horacio y Cicerón; por lo tanto, había entendido muy bien la renovación petrarquesca" ${ }^{11}$. Esto, sin embargo, no sólo era altamente innovador en su tiempo sino también en el nuestro, dado que los aspectos medievales se han destacado en Boccaccio (Branca 1992) y de ellos no se libra ni un Lorenzo Valla (Vilallonga 2001, 487); pero Petrarca continúa siendo el indicador del Humanismo: «ni siquiera serfa exagerado afirmar que el humanismo fue en muchos puntos el proceso de transmisión, desarrollo y revisión de las grandes lecciones de Petrarca» (Rico 2002,11). Ahora, con el notario barcelonés subrayamos el proceso crí-

9 Per a un ver coneixedor del curs del pensament renaixentista el problema no ts mai si Bernat Metge és ja un escriptor humanista o un pensador molt tocat de les inquietuds intel-lectuals renaixentistes, ans com ha estat possible un Bernat Metge a Barcelona l'any 1398* (Batllori 1995, 26). Extrafia evidentemente su grado de agudeza crítica y estética junto con una expresión tan liberada - baste tener presente las calificaciones de hereje epicúreo, etc., procedentes de la critica del siglo XX - frente a los indices de sensibilidad minoritaria de aquel entorno. Nuestra península no era la itálica, a pesar de los contactos con aquellos humanistas a través de Avinón - donde estuvo Metge como embajador - , Nápoles y Bolonia.

10 El hecho cronológico explica también que la tarea de estos primeros humanistas catalanes no fuera, como en el siglo XV, contra el latín medieval degenerado (Nadal-Prats, II, 349), sino a favor del ennoblecimiento del romance, ansia a la que se llegará después en las diversas literaturas. Según estos historiadores de la lengua, «Metge és qui porta a un punt de més alta perfecció classica aquesta catalanització de la prosa de Cicero" (Nadal-Prats, I, 472); pero en cuanto al hecho de preferir el catalán es diffcil distinguir en que medida se debe a una fehaciente adscripción lingulistica 0 al dominio del vulgar por encima del latín (Butiná 2002 b, 39 y n. 47). En cualquier caso, Metge segula puntualmente las lecciones de Boccaccio, téricas - del Genealogiae deorum (ib., 45-47) - y practicas; éstas no se pueden constatar a través del Decamerón, pero si del Trattatello in laude di Dante y del Comento alla Divina Comedia (Butiná 2002 a, especialmente 302-309 y 374-375), al fin y al cabo, pues, en la línea de Dante y el brillo del sole nuovo del vulgar. Por vfas distintas - por tanto, sin pretender valorar la prelación-, se adelantó a la recuperación que para las lenguas vemáculas tardaría aún en llegar.

"Al juego de fuentes petrarquesco-ciceroniano, así como al influjo agustiniano y al de Horacio, ha ido llegando también la crítica recientemente, como recojo en Butifía 2002 a, 12-13, n. 5; 193, n. 55. Los trabajos en que anuncie esa lectura de Lo somni fueron: Metge, un bon lul.lista $i$ admirador de Sant Agustf, «Revista de Pilologia Románica* XI-XII (1994-95), 149-170; Dues esmenes al «De remediis» $i$ dues adhesions al «Somnium Scipionis» en el prehumanisme catald, «Revista de L'Alguer 5 (1994 a), 195-208; Cicerón, Ovidio, Agustin y Petrarca tras *Lo Somni* de Bernat Metge, «Epos» X (1994 b), 173-201; Al voltant dels conceptes de la gentilitat i el profetisme a «Lo somni» de Bernat Metge i la font del « Secretum», «Llengua i Literatura. Revista anual de la Societat Catalana de Llengua i Literatura» 12 (2001), 47-75. Tales fuentes se asumen en El somni d'una cultura: «Lo somni» de Bernat Metge de Stefano M. Cingolani (ed. Quaderns Crema, Barcelona 2002), en Actes del III Col -loqui «Problemes i Mètodes de Literatura Catalana Antiga»; Literatura i cultura a la Corona d'Arago (Publicaciones de la Abadía de Montserrat 2002) y en la edición de Lo somni de L. Badia (ed. Quaderns Crema, Barcelona 1999, $32,36,230-231$ ). 
tico, porque arremete contra aspectos medievalizantes del maestro en lo filos6fico-moral y revela, a través de las fuentes, cómo le hace culpable de la corrupción boccaccesca, o sea del cambio de actitud del nuevo cantor del amor hacia el misoginismo (Butiñ́ 2003 a). O sea que, muy parad6jicamente, para Metge, los rasgos medievalizantes boccaccianos se deben a su mentor, quien a su vez es mentor de todos los humanistas.

Por otro lado, desde mediados del siglo XV, en los círculos valencianos, autores como Ausias March, Martorell o Roís de Corella beben en la tradición clasicista.

Otra obra de tema eminentemente humanista ha sido objeto de edición y estudio por parte de Antoni $\mathbf{M}^{\boldsymbol{N}}$ Badia i Margarit: Les Regles d'esquivar vocables $i$ "la questió de la llengua ${ }^{12}$; es producto de finales de siglo $\mathrm{XV}$, tras el influjo del espíritu del Magnánimo, bajo el cual se alcanzó el cenit en estas letras según el Dr. Badia (1996, 167). Asimismo, a la corte napolitana del rey Alfonso se habra vinculado - desde la publicación del manuscrito, a comienzos del siglo $\mathrm{XX}$ - la preciosa novela caballeresca del Curial e Gilelfa; tanto esta vinculación como su carácter humanista, que parecen ser progresivos por parte de la crítica (Ferrando, Alemany...), los he defendido desde 1987, manteniendo a la vez una hipotesis de autoría en el notario y embajador del Magnánimo, mosén Gras, autor de la Tragédia de Lanfalot, versión humanística de la Mort Artu (Butiñá 2001, 211-334).

Estos datos indican que el cauce de los estudios del llamado Humanismo catalán, a pesar de la potente y masiva interrupción, no ha desaparecido ${ }^{13}$. Además, la vigencia del concepto se ve amparada al verse enmarcada en la producción hispánica, a la luz de la conclusión del estudio inicialmente citado (González Rolán... 2002) respecto a los orígenes del movimiento en España en el siglo $X^{14}$. O sea que a la recuperación de la tradición humanista en las letras catalanas se le ofrece un apoyo en los estudios de Filología Hispánica, llevados a cabo por estudiosos de la Filología Clásica:

12 Institut d'Estudis Catalans, «Biblioteca Filologica» XXXVII, Barcelona 1999. Han aparecido valiosos comentarios de G. Colón, E. Duran, A. Ferrando, M. Vilallonga (Somnis i realitat en els nostres humanistes del Renaixement, «Estudis Romanics* XXIV, 2002, 207-210); con Merct Montagut y M" Lluise Ord6hez he elaborado una resefha en *Revista de Filologia Espantolaw LXXXII (2003), 279-288.

13 Debo aportar aqur la consideración de Albert Hauf al referirse a la tradición a la que se adscribia Batllori, ktradició representada pels Rubio pare i fill i tambe per Mart de Riquer; tradició ara en bona part recuperadia en els nombrosos treballs de Jtalia Butinya i d'altres, després d'una etapa d'aparent ruptura dialectica, representada pels treballs dels qui, com ara Lole Badia i Francisco Rico, són partidaris d'una mes limitada opcio filologicax (VV AA 2001, 52).

14 Quiero matizar que es de esperar que también con flexibilidad cronológica no se excluya el dialogo clasicista Lo somni, que Metge presenta al rey en 1399. Por otro lado, es reconfortante poderse reconocer dentro de la expresión men Espafia* según reza el título de estos estudiosos, pues en otros casos (D. Yndurdin, Humanismo y Renacimiento en España, od. Cátedra, Madrid 1994, o A. Gómez Moreno, Espatta y la Italia de los humanistas. Primeros ecos, «Biblioteca Románica Hispánica. Estudios y ensayos* 382, ed. Gredos, Madrid 1993) no se atendra practicamente a la producción en las distintas lenguas vernáculas. Cosa que quizás pueda justificarse por la falta de consenso interno. 
«Las investigaciones realizadas en estos últimos diez años, de las que damos cumplida cuenta en nuestra bibliografía, demuestran a las claras que en la Castilla de mediados del siglo XV y también en Cataluña: a) se difunden muchas de las obras clásicas puestas en circulación por los humanistas italianos; y b) se propagan también las traducciones latinas de obras griegas así como los escritos originales de los más eximios representantes del humanismo filologico-literario, como Leonardo Bruni, Pier Candido Decembrio, Poggio Bracciolini, Giovanni Aurispa, etc.

Esto nos lleva a concluir que el humanismo filologico-literario se difundi6 y arraigo en Espania a lo largo de la primera mitad del siglo XV, que Nebrija no fue ni mucho menos el primer restaurador e introductor de los textos clásicos en la Península, pues con bastante anterioridad fueron leídos, comentados y traducidos autores como Cicerón, Séneca, Ovidio, Salustio, Valerio Máximo, Vegecio, Homero, Platón, Aristóteles, Plutarco, Luciano, etc., y finalmente que la concepción que algunos filologos, sobre todo ingleses, han tenido de la Castilla y Cataluña del siglo XV no se corresponde con la verdad de los hechos.

En un trabajo recientemente publicado ${ }^{15}$ hemos tratado de ver si los dos sentidos, uno restringido y otro más amplio, que A. Fourrier ${ }^{16}$ da al término humanismo son de aplicación a la Castilla de la primera mitad del siglo XV. El humanismo en sentido restringido correspondería al conocimiento de los autores logrado a través de la lectura, comentario y traducción de sus textos; el humanismo en sentido amplio se identifica con la asimilación y absorción de los modelos culturales clásicos, cuyo reflejo más evidente es la imitación. En el siglo XVI, concretamente en 1549, Joachim du Bellay se referira a esta imitación en un lenguaje metafórico, que ejemplifica con imágenes digestivas, según el cual es necesario imitar a los mejores autores devorándolos para después de haberlos digerido convertirlos en sangre y alimento ${ }^{17}$. Pues bien, durante el reinado de Juan II de Castilla (1406-1454) hay muestras claras, evidentes e inapelables tanto de un tipo de humanismo como del otro. Es más, durante este perfodo, la mayorfa de los traductores de textos clásicos son hombres de letras que poseen además obra original propia, bien en latín, bien en castellano, bien en ambas lenguas a la vez, y en algunos de ellos, como Juan Rodríguez del Padron ${ }^{18}$ o Pedro Diaz de Toledo, en esa obra original se encuentran interesantísimas imitaciones de autores clásicos como Ovidio y Platón.

Así pues, en la Castilla anterior al reinado de los Reyes católicos existieron litterati, 0 si se quiere prehumanistas o protohumanistas, competentes

15 T. González Rolán \& P. Saquero Suárez-Somonte, El «Axioco» pseudo-latino traducido e imitado en la Castilla de mediados del siglo XV: edición y estudio de la versión romance de Pedro Diaz de Toledo y de su modelo latino, «Cuadernos de Filología Clásica. Estudios Latinos» 19 (2000), 157-197.

is Se refiere a L'Humanisme Médieval dans les Litteratures Romanes du XIF au XIV' siecle (1964).

17 Alude a Deffence et Illustration de la langue franfoyse y remite a T. Hermans (1985).

is T. González Rolán \& P. Saquero Suárez-Somonte, Las cartas originales de Juan Rodriguez del Padron: edición, notas literarias y filologicas, «Dicenda. Cuadernos de Filología Hispánica» 3 (1984), 39-72. 
conocedores de las litterae, es decir del latín, que, además de ser especialistas en derecho o teología, fueron creadores, literatos. Alfonso de Cartagena, Juan Rodríguez del Padron, Alfonso de Madrigal (el Tostado), Pedro Díaz de Toledo etc., fueron litterati en el triple sentido anteriormente sefialado, es decir conocedores del latín, letrados o teologos, y literatos, hombres de letras» (González Rolán... 2002, 62-63).

Al final de este libro se recogen los versos en que Juan del Encina, en Triunfo de la Fama, incluye como varones doctos a escritores españoles junto a otros griegos y latinos (ib., 64); sus mundos se han fusionado naturalmente, pues, en una nueva cultura:

«Allí vi también de nuestra nación muy claros varones, personas discretas, aca, en nuestra lengua, muy grandes poetas, prudentes, muy dotos, de gran perfeción;

los nombres de algunos me acuerdo que son aquel ecelente varón Juan de Mena y el lindo Guevara, también Cartagena, y el buen Juan Rodriguez, que fue del Padrón.»

A su lado me atrevería a poner - completando el esfuerzo innovador que hace este investigador por reunir el bagaje de las dos Coronas -, un fragmento del Curial que he destacado alguna vez ya con parecido talante. Es una escena en la que se adelanta el feliz final y donde se da a entender, por medio de un sueño de la protagonista, que ha alcanzado el triunfo en la virtud amorosa. Tiene lugar en un clímax de hibridación cultural, con absorción de la tradición clásica greco-latina; habría que ver - dice el autor - «la gran festa e lo gran dançar» de aquellos modélicos enamorados, algunos de los cuales eran casos abominados según la moral tradicional:

«Aquí vírats Tisbes e Piramus fer-se maravellosa festa, Flors e Blancaflor, Tristany e Ysolda, Lançalot e Genebra, Frondino e Brisona, Amadís e Uriana, Phedra ab Ypolit... Troyol e Briseida, Paris e Viana, e molts altres, dels quals, per no ésser lonch, me callarè (ed. cit., III 230).

Este sincretismo no es de todos modos exclusivo ni revolucionario, como tampoco lo es el concluir que las corrientes coinciden y a la vez son distintas en los diversos países y literaturas, según dijimos al principio respecto a las dos Coronas $^{19}$. Observaba en mi libro sobre Metge que, «del Humanismo castellano

19 En González Rolán... 2002 se repasan diferentes tipos de absorciones de la tradición clásica, así como se recoge el vaivén de esta tradición, que, fuerte primero en Castilla, sobre todo gracias a la Escuela de traductores de Toledo, pasa a Aragón en el siglo XIV (ib., 59); luego, en el XV se percibe en ambas Coronas bajo el sello de los italianos (ib., 62-63), para irradiar nuevamente desde all gracias a Nebrija. 
a estos inicios en las letras catalanas hay un abismo; pero no por tratarse de lenguas distintas, sino porque los humanistas utilizan distintos lenguajes. Ni superior ni inferior: distinto; y más aún en el caso de Metge, que se separa de los autores castellanos en el tiempo, pero también de los italianos, si corrige a éstos o anticipa soluciones que se iban a dar con posterioridad ${ }^{20}$. Al igual que hay que distinguir esta producción respecto de la italiana por contar con autores que aplican en géneros artísticos de creación los renovadores contenidos que allí, después de Boccaccio - en quien han aprendido eficazmente los catalanes-, se expresaban sólo en cartas y tratados ${ }^{21}$; lo cual también es distinto, no superior ni inferior.

Por lo tanto, aunque ya dijimos al comienzo que no consideramos estrictamente el Humanismo como un período, si se da una transicion entre la Edad Media y el Renacimiento, manifiesta a través de testimonios literarios que no son aquello ni esto, tenemos Humanismo en ambas Coronas, con modos, rasgos y momentos dispares; pero si se exige que la valoración clasicista alcance un calado social, no hubo Humanismo catalán, ni tampoco castellano poco después, ni en muchos otros países a pesar de darse con diferencia de siglos. Y si para denominarlo Humanismo hemos de considerar una moda ambiental, que por lo general lleva añadida una carga de superficialidad e intereses, entonces ya no sería evidentemente en rigor Humanismo» (Butiñá 2002 a, 17-18). ${ }^{22}$

19 En González Rolán... 2002 se repasan diferentes tipos de absorciones de la tradición clásica, así como se recoge el vaivén de esta tradición, que, fuerte primero en Castilla, sobre todo gracias a la Escuela de traductores de Toledo, pasa a Aragón en el siglo XIV (ib., 59); luego, en el XV se percibe en ambas Coronas bajo el sello de los italianos (ib., 62-63), para irradiar nuevamente desde allí gracias a Nebrija.

20 Aunque no se trata de ninguna falaz carrera, hay que anotar que no parece oportuno establecer un contraste entre este autor y la producción coetánea en Castilla, dado que hasta el reinado de Juan II no se efectúa la ruptura de su aislamiento ni se establecen estrechas relaciones con la cultura italiana (González Rolán-Moreno-Saquero 2001, 13. Sobre este contraste, véase también R. Recio 2001, 300-301).

21 Esta idea, que expuse en 1997 (Sobre la proyección de los trecentistas italianos en la introducción del Humanismo en la Corona de Aragón, «Cuademos de Filología Italiana» IV, UCM, 265-277), la desarrolle en La proyección de Boccaccio en las letras catalanas de la Edad Media, en el Congreso sobre La recepción de Boccaccio en España, Universidad Complutense, 2000, al que asistían, entre los italianistas, V. Branca o M. Picone (ponencia publicada en las actas del mismo, 2001, 497-533), y por parte de la catalanistica: L. Badia, J. L. Martos y J. Ribera i Llopis.

22 «Realment ningú no pot creure en la uniformitat i l'estatisme de l'humanisme ... Per què, doncs, el nostre humanisme ha de ser mesurat en relació a un humanisme italia pretesament en estat pur? En relació a quin dels humanismes que es donen a la península italiana? Crec que ja és hora de bandejar els problemes d'identitat que ha patit l'humanisme catala, des del seu mateix naixement com a moviment. I parlar lliurement d'humanisme, igual com parlem de noucentisme o de modernisme* (Vilallonga 2001, 481). Es decir, en las diversas literaturas se habla de Humanismo, conscientes de diferencias cualitativas o ambientales; asi, Miguel Ángel Pérez Priego $(2001,494)$ distingue estos matices en Santillana, autor que, como el personaje Curial - principe de Orange al final-, está más cerca del modelo de Maquiavelo que de los héroes de las crónicas, aunque todavfa les resonaran en la cabeza a ambos y vistieran de un modo parecido a ellos. 
El movimiento humanista en la Corona catalanoaragonesa se caracteriza por su carácter temprano $0^{23}$ y por manifestarse en un primer momento - el de la Cancillerfa barcelonesa - en individualidades ${ }^{24}$, que nos dejaron obras de acusado relieve, según venimos diciendo, desde el siglo XIV en lengua vernácula ${ }^{25}$. Pero es sabido que aquellas novedades no calaron en los hábitos culturales de la sociedad y fueron captadas sólo por una muy selecta minoría ${ }^{26}$, la cual se consideraría conflictiva y peligrosa para las mentalidades tradicionales. Bien lo atestigua la exigente y elegante labor traductora del dominico Antoni Canals (Riquer 1964, 450), quien en el prólogo al Africa petrarquesco, previene de la paganización moral ante la fascinación de sus virtudes, cosa que quiere reconducir ${ }^{2}$. Aquella minoría incluso quizás haya que reducirla a círculos de amigos ${ }^{28}$, pero no debe descuidarse por el hecho del número, pues eran élites, luego influyentes; $y$, a la luz de la historia, decisivas.

Aquellas obras en lengua vulgar, precisamente a causa de su inmediatez con Italia, presentan una percepción del nuevo talante bastante pura ${ }^{29}$. Sin embargo,

23 \&La catalana quindi e una letteratura europea che ritarda a partire, ma che alla fine del Medioevo sembra anticipare i gusti della nuova eraw, Compagna 2002, 595. A pesar de ello, el Humanismo no alcanza las Universidades hasta el reinado de Fernando el Católico; el del siglo XVI, pues, kno provenia pas del primerenc Humanisme catalano-aragonès dels nostres trescentistes Juan Fernández de Heredia i Bernat Metge; era un Humanisme de nou encuny, sorgit de dues influències foranes: primer, la de Nebrija; despres, la d'Erasmex, Batllori 1995, 267.

24 En general, hacia la consideración de una filosoffa espafiola - y en cuanto al Humanismo hispánico en particular - aplica parecido comentario Batllori $(1995,28)$. Aunque, de todos modos, incluso en Italia la audiencia humanista era minoritaria, como distingue Raffaelle Morabito al referirse a la difusión del Griselda entre los hombres doctos y la comprensión de las seniles (Morabito 1993, 29-30, 34 passim).

${ }^{25}$ Quizás está pendiente de más estudio la ascensión del catalán dignificado frente al latín, a la luz de indices comparatistas como el aluvión de catalanismos que penetra en el castellano en el siglo XV, hecho al que se refirio Jose Antonio Pascual en las II Converses Filoldgiques. (Vease tambien la n. 10 supra).

${ }_{20} \mathrm{El}$ contraste con Italia lo viene a retratar una frase de F. Rico al decir que es kel drama del prehumanismo espafiol» 2002 b, 183. (Pero véase también la n. 24 supra).

${ }^{27}$ El caso de Canals, qujen probablemente no debe calificarse de humanista a pesar de su exquisita labor traductora, no puede entenderse sin ese incipiente movimiento, que tanto le preocupaba y de cuya fuerza debió percatarse, ya que el prevenir de sus peligros es quizás el determinante principal de su obra.

23 Estos amigos, que participaban de una nueva sensibilidad, aparecen a veces en las obras de Metge: la Medecina, poema que es una receta en clave y burlesca, se la dedica a mosen Bernat y las dos cartas que envuelven el Griselda se dirigen a madona Isabel de Guimera, quien nos consta como amistad ya familiar (ed. Riquer, 118 y n. 1); así como se sobreentienden en el Libre de Fortuna e Prudencia (J. Rubi6 1992, 148). Y, sobre todo, la amistad es palpable en los libros I y II de Lo somni, donde, en su conversación con el monarca fallocido, se hace elocvente a traves de la manifestación de dolor por su ausencia (ed. Riquer, 174) o se refleja bellamente mediante el De amicitia ciceroniano (ib., 202-203 y n. 28-29).

29 Aunque la discusión en cuanto a la existencia de un Humanismo puro parece ser que se puede alargar mucho y habra que partir de la aclaración conceptual antes de pronunciarse en las distintas literaturas, para trazar luego las líneas generules del entrelazado panorama europeo - que, aun siendo un testimonio muy dispar, bien atestiguan las Griseldas -, algunos se decantan por el pesimismo de conseguir mas que el cultivo de los studia humanitatis y a negar una verdadera conciencia de recuperación del primer Humanismo, el clísico; asf, Jocelyn N. Hillgarth en el prologo a Gabriel Ensenyat y Maria Barcel6, Els nous horitzons culturals a Mallorca al final de l'edat mitjana ( $\propto$ Menjavents» 36, Palma 2000, 10). 
es muy común consultar estudios sobre el Humanismo hispánico sin referencias a Metge o a Martorell, así como también ensayos europeos que ignoran las aportaciones hispánicas, y es muy frecuente que los latinistas desconozcan las obras de las lenguas romances, etc., según el ya mencionado defecto de la parcelación $^{30}$. Por lo que hay que concluir con Rico que: «Cuando progrese la investigación, habrá que diseñar un paradigma del humanismo español harto más amplio (y problemático)», 2002 a, 194.

Es preciso, pues, dentro del panorama general y al margen de excepciones ni prioridades, hacer escuchar aquellas voces tan válidas de los orígenes de la

También se desprende una sensación negativa del mismo título onfrico de Rico (2002 a), quien comienza refiriéndose al proyecto no realizado de «un mundo construido sobre la palabra antiguaw (19) y, finalmente, a la complejidad del panorama y al lamento tan generalizado de la falta de estudios (194); en cuanto al Humanismo catalán, salva la figura de Bernat Metge, dejandonos a la expectativa de un pronunciamiento $(1983,291)$. Lola Badia asi mismo obvia a este autor: «Bernat Metge pot produir molts miratges perquè Es un cas únic, al meu entendre, genial, sense precedents ni continuittat $(1996,22)$. Por otro lado, el tutulo del estudio de $\mathbf{S}$. Cingolani citado en la $\mathrm{n}$. 11 supra parece situar a la cultura catalana dentro del contexto de un Humanismo fantasmagórico e irreal; según la resetha que le hace Galves: *Contra el que clarament carrega Cingolani és contra el 'somni d'una cultura'; contra el somni especific de la cultura filologica catalana que, per dignificar la seva tradicio, vol veure en Lo somni un humanisme que no és aital» (reseña citada en la n. 3 supra).

3o Ante tan penosa situación son muy interesantes los enfoques transversales, como el de Gonzalez Rolán en las I Converses Filoldgiques. Por ejemplo, distinguiendo los niveles de la conciencia de recuperación frente a los de realización, o bien relacionando la conciencia lingurstica y la literaria; es decir, cuándo, por qué y cómo escriben en una u otra lengua y qué tipo de relación presenta su elección con el carácter de la obra. Entre tantas otras cosas sobre las que convendrfa dialogar en relación con el Humanismo.

Por mi parte, he de decir que, aunque hace unos 15 affos que publico insistentemente sobre distintos aspectos de las letras catalanas empleando el dificil concepto del Humanismo, no habla intentado antes enfocar el movimiento (salvo en lo referente a la periodización interna, n. 67 infra); si lo hago ahora (sin pretensiones ordenadoras ni entrar en disquisiciones complejas, como supondria emplear el prefijo pre ante el vocablo Humanismo), es porque considero que la carestía general se agrava debido al desconocimiento mutuo ya aludido y ante la necesidad de seguir dilucidando. De todos modos, mi teorización se atiene al empetio de analizar parcelas con visos de comunicación y de amplitud, a fin de que pueda servir para recuestionar planteamientos, es decir para avanzar.

31 Desde una visión panorámica, precisamente el Humanismo hispánico ofrece una rica amplitud, desde los orfigenes en la Corona de Aragón al esplendor del Humanismo renacentista en la de Castilla. Por otro lado, adin cabe decir que los movimientos de amplio espectro - tambien el Barroco, Modemismo, etc. - no pueden restringirse al ámbito filológico, pues no se cifien solo a la Filologia.

En la línea fundamental de continuidad profunda del Humanismo - de Petrarca a Erasmo - que sigue aquel estudio, incluyo a Metge desde luego, a pesar de - pero también a causa de - su disidencia petrarquesca. Una reflexión a través del indice explica en parte esta inclusion: en el libro de Rico solo hay una referencia a Boccaccio cuando en mis estudios suele andar igualado con -o supera - las referencias a Petrarca. Cabe recordar que la concepción del Humanismo, incluso dentro del enfoque filologico, se escinde en profundidad ya en los orfgenes, en tiempos de Salutati.

32 Todo el Griseldis arranca de la discusión sobre la virtud, a causa de haber negado un amigo de Petrarca veronés que fuera posible el grado de Griselda; Metge, sobre las mismas palabras, salta indignado manteniendo que es tal y como se recita, y fulminando a quien lo niegue (Butif́a $2002 \mathrm{~b}$, 24-27 passim). 
discusión humanista; sobre todo la de Metge, que, aunque no haya influido desde una lectura profunda (n. 23 supra), es muestra muy reveladora de su misma entidad. Es decir, más que deducir que el Humanismo no existe por ser demasiado etéreo o bello, como se hace al principio de El sueño del Humanismo: «Fue un sueño, porque vislumbró el trazado de la ciudad ideal, pero le faltaron las piedras y herramientas para construirla» (Rico 2002 a, 19), considero que el movimiento no anda lejos de los que son conscientes de tal imposibilidad, pero advierten o denuncian las limitaciones y discuten al respecto ${ }^{32}$. Baste recordar las diatribas de Valla y de Salutati, que tenían un precedente en las de Petrarca y Boccaccio. Discusión esta última que bien captó Metge, al igual que la captaron las miniaturas de los códices italianos (Butiñá 2002 b, 30-33 passim), y es la que genera las primerísimas traducciones del Griselda. Metge hace al respecto una referencia en $L o$ somni que vale por la loa boccacciana más extrema (Butiñá 2002 a, 374-375, y 2002 b, 45-49); y aún, en el III y IV libro del diálogo, el rechazo del Secretum está altamente dignificado, con la flor y nata de los clásicos. $Y$ todo esto, tan efímero pero tan noble, estas graves y añejas discusiones, están en los origenes del Humanismo hispánico. Por lo que hay que incluirlas en una visión de conjunto, dado que son hechos particulares que se enmarcan en otros generales. Además, su terminología y periodización dentro del mundo de la producción hispánica ${ }^{33}$ es especialmente interesante cuando ha sido negado por historiadores europeos de la Literatura que lo desconocen o minusvaloran (González Rolán... 2002, 17-18) y cuando es tema que afecta a la relación de España con Europa. ${ }^{34}$

Este estado de cosas explica que nos hayamos fijado en primer lugar en la Literatura catalana - desde cuyos estudios se ha negado con tanto vigor este

${ }_{33}$ Para el interes que hoy despierta remito simplemente al $*$ Boletín de estudios sobre el Humanismo en Espafia II, ed. por Jenaro Costas Rodriguez y Leticia Carrasco Reija, UNED 2000, 176 pp., donde se dan las siguientes divisiones por materias: Humanismo general, Lengua latina, Literatura latina, Lengua y Literatura griegas, Otras disciplinas, Estudios sobre tradición literaria, Humanismo en las regiones de Espatia, Humanismo en las Universidades españolas y Humanismo extranjero. Tambien, a las páginas iniciales de los trabajos de Tomás González Rolán y Pilar Saquero (2000, 2001, entre otros) o bien a estudios sobre humanistas, como Alfonso de Cartagena (los autores recién citados más Antonio Moreno, 2001), o a tesis doctorales, como las de Juan de Lucena y Metge,a cargo de Jerónimo Miguel y Miguel Marco.

34 La defensa del Humanismo hispánico fue transitada con firmeza por Batllori: «Sabido es que el concepto del Renacimiento plantea múltiples dificultades interpretativas, agravadas en el caso del Renacimiento espafiol por las susceptibilidades que genera el mítico 'problema de España': la relación de Espafia con Europa (...) En primer lugar, me parece que debe subrayarse su beligerante reivindicacion de la presencia del Renacimiento en Espaffa contra la tendencia sistemática de buena parte de la historiografía alemana (de Morf a Klemperer pasando por Wantoch) a negar su existencia» (García Cárcel 1990, 52 y IV; la última referencia está reproducida del prólogo a Humanismo y Renacimiento. Estudios hispano-europeos de Batllori). También lo defendio J. Rubio (1990, 175), rechazando a Ch. S. Baldwin.

Pero, por otro lado, recogemos observaciones recientes como la de Martinez Romero $(2002,47)$, para quien la polémica acerca del antihumanismo de san Vicente Ferrer no habría existido si se hubiesen planteado las cuestiones, como hizo Karl Kohut, desechando todo el Humanismo de la literatura espariola. 
Humanismo $0^{35}$ o bien se repiten teorías que, según observamos, anularían también el Humanismo hispánico - y que pasemos en segundo lugar a lo que tiene de hecho la precedencia: el comentario térico y general.

Así las cosas, si el enfoque de estudio del profesor González Rolán nos permite saltar por encima de la conflictividad acerca de la definición de Humanismo, pues a la luz del recorrido de la tradición clásica se establecen unas bases conceptuales, nos es de gran interés asimismo el libro de Francisco Gutiérrez Carbajo, que sigue movimientos y épocas literarias a la luz de los últimos avances en la investigación teórica, profundiza en la periodización de la historia literaria y abstrae las líneas más actuales $(2002,34-38$, páginas que dado su interés vamos a reproducir en gran parte), porque en algunos aspectos contribuye a dilucidar aquella/s polémica/s. Por ello, aunque sea un enfoque amplio, conviene traerlo a la memoria y efectuar su aplicación a nuestro contexto.

Comienza Gutiérrez Carbajo distinguiendo dos tesis contrapuestas en la división de la literatura en épocas o períodos:

«la nominalista, que considera el concepto de etapa o período como una simple etiqueta intercambiable, desprovista de todo contenido real, y la metafísica, según la cual las épocas o períodos son entidades transhistóricas (Aguiar e Silva, 1979: 245; Amoros, 1979: 147). La actitud nominalista no tiene en cuenta uno de los aspectos esenciales de la actividad literaria: la existencia de estructuras genéricas que, desde muchos puntos de vista, hacen posible la obra individualizada. Aguiar e Silva (1979: 245) expone como ejemplo del escepticismo de esta corriente nominalista las palabras que Paul Valéry escribió en Mauvaises pensées, según las cuales resulta imposible pensar con palabras como clasicismo, romanticismo, humanismo, realismo, porque nadie mata la sed ni se embriaga con los rótulos de las botellas. Aguiar e Silva invierte el planteamiento y advierte que lo importante es que el rótulo no sea arbitrario, que corresponda al contenido, y que por tanto la etiqueta tenga justificación y legitimidad. A la tendencia metafísica pertenecen algunos críticos de la escuela alemana, como Cysarz, que concibe la periodización "como línea y no como herramienta, como forma esencial y no como forma de ordenación, que revela la estructura total de una ciencia, y, a través de ésta, un sector y hasta tal vez un hemisferio de todo el globo intelectual'. No se trata, por tanto, de medir u ordenar, sino de ejercitar 'la función fundamental de una interpretación de la obra literaria y una reflexión sobre la vida'. Y todo culmina, como observa Amorós (1979: 147-148), con la pretensión de lograr 'la definitiva superación de la antítesis superficial entre el individualismo y el colectivismo'.

Aguiar e Silva, fundando alguna de sus observaciones en la filosofía de Heidegger, comenta que una concepción metafísica de los periodos literarios sólo

3s Baste hojear las guías bibliograficas de la literatura catalana medieval o las historias de la literatura catalana, donde el concepto - aun cuando no se ataca - suele ser inexistente. Hoy, se ha desarraigado hasta tal punto que hay libros de estudio donde no se mencionan tales sintomas y, en los más resumidos, el paso de Llull al Tirant aparece sin gradaciones conceptuales, sin goznes que expliquen los cambios. 
es posible anulando la historicidad del hombre, incluso cuando un determinado clasicismo o romanticismo es presentado como variación histórica de una entidad básica y atemporal.

Es preciso, por tanto, recurrir a criterios literarios para fundamentar y definir las épocas y los movimientos, atendiendo sólo en la medida que sea necesario a criterios procedentes de la política, de la sociologia y de la religión. Juan Oleza constata, sin embargo, que la mayoría de las historias literarias aceptan sin discusión los períodos fijados por los historiadores políticos, siendo asi que deberfan primar los criterios puramente literarios: 'Si nuestros resultados coinciden con los resultados de los historiadores de la política, de la sociedad, del arte y de la cultura, nada hay que objetar. Pero nuestro punto de partida ha de ser el desenvolvimiento de la literatura como literatura' (Oleza, 1976: 10). Hay que reconocer, sin embargo, con Andrés Amorós, que los rótulos con los que denominamos habitualmente los perfodos literarios tienen un origen muy variado. A veces proceden, en efecto, de la historia política y hablamos de la epoca victoriana, de Felipe II, de la Restauración. Otras, en cambio, tienen origen eclesiástico: Reforma, Contrarreforma. $O$ erudito: Humanismo. $O$ artistico: Barroco, Manierismo, etc. La mezcla de criterios parece inevitable, aunque en general la investigación se encamina por una historia literaria constituida por movimientos literarios y dividida en épocas o períodos delimitados por criterios predominantemente literarios.

No parece extraña esta supeditación de la periodización en literatura a factores externos, como los políticos y los sociológicos, si tenemos en cuenta, como observa Cysarz (1984: 107), que tradicionalmente las discusiones periodologicas estaban reducidas a la historia universal, y que los historiadores de la literatura iban 'a remolque de los historiadores políticos'. Sin embargo, no conviene olvidar que ya en nuestro país fue abordado este problema en el siglo XIX por Menéndez Pelayo, entre otros. (...)

Obviando este tipo de generalizaciones ${ }^{36}$, parece oportuno retomar la concepción de 'periodo' de Wellek expuesta al principio: 'Una sección de tiempo dominada por un sistema de normas, pautas y convenciones literarias, cuya introducción, difusión, diversificación, integración y desaparición pueden perseguirse' (Wellek-Warren, 1974: 318). Esta definición, como observa Aguiar e Silva, obvia las tesis metafísicas y nominalistas, así como las tipologías de tenor filośfico o psicológico, ya que los caracteres distintivos de cada periodo se consideran enraizados en la propia realidad literaria y son indisociables de un proceso histórico determinado. Al definir Wellek el períado 'como un sistema de normas, pautas y convenciones literarias', lo está caracterizando por la convergencia organizada de varios elementos. Esta convergencia nos recuerda las relaciones de interdependencia defendidas por los estructuralistas, y algunos de los presupuestos de los formalistas y de la estética de la recepcion. Por su parte, si la teoría de Segre y otras expuestas con anterioridad

36 Se ha referido aqui a una tipologia mimética de ciclos reiterados, como los biologicos (juventud, madurez..., primaveral, otofial...). Ésta fue la propuesta de L. Badia para el perfodo catalán $(1988,46-49)$. 
intentaban conjugar la visión diacrónica y la sincrónica, algo semejante defiende Giulio Carlo Argan respecto a los períodos literarios, pues Estos se articulan en un 'área espacio-temporal en que determinado sistema de signos desarrolla y agota todas las posibilidades de significación' (Aguiar e Silva, 1979: 247). Por otro lado, en la definición de Wellek cada periodo se define por el predominio - no por la presencia exclusiva - de determinados valores. Cada época o período, por tanto, no se caracteriza por una perfecta homogeneidad estilística, sino por el predominio de un estilo determinado. El estudioso de los problemas del Renacimiento y del Barroco, Eugenio Battisti, se ha referido con certeras palabras a este mismo asunto: 'El reconocimiento de la presencia cronológica de diversos componentes, de los que unas veces predomina uno y otras veces otro, pero sin excluirse en absoluto, aunque se trate de un ambiente restringido o de un período limitado, es la única solución admisible, aunque complique y no simplifique el panorama. La posibilidad de reducirlo todo a unos pocos conceptos simples es un mito metodológico, fruto exclusivamente de la ignorancia o de la pereza' (Battisti, 1962: 47)...

Coutinho (1964: 22) argumenta que la 'descripción de los perfodos en sus realizaciones y fracasos, proporcionará un cuadro del continuo desarrollo del proceso de la literatura como literatura'. En la línea de Coutinho, otros investigadores son partidarios de un estudio comparatista de las distintas epocas y movimientos literarios, ya que los más significativos como el Renacimiento, el Barroco, el Romanticismo o el Realismo no son exclusivos de una literatura determinada, sino que extienden sus redes formales y significativas a otras literaturas nacionales. (...) Estas relaciones no han de entenderse como influencias que parten de una manifestación y determinan la evolución de las demás, sino como un complejo sistema de relaciones dialécticas (Wellek-Warren, 1974: 161) que las distintas manifestaciones tienen entre sí.

Suscribimos la opinión de Max Wehrli, según la cual las epocas y movimientos literarios no han de concebirse como sistemas rgidos, sino como conceptos móviles, 'a través de los cuales, los distintos rasgos estilísticos individuales se retienen solo en sus relaciones, interdependencias y cambios..$^{38}($...) Lo que el lector y el historiador de la literatura perciben, es un fluir de sucesos, de vidas de autores, de obras y de fechas. Suelen ser claras las culminaciones de los procesos. No es fácil, en cambio, deslindarlos en la vaga zona en la que los procesos se inician o terminan. Porque, por otra parte, ¿que etapa o momento no es 'de transición'? (Amoros, 1979: 154-155). Metodologicamente la época

37 Sigue a contimuación una muestra de varias épocas, en Francia y Esparia, acenca de estos asertos.

30 Influyen, pues, un cúmulo de procesos culturales. Tras seguir J. Rubio el cambio de los orfgenes humanistas en la lengua y el estilo, afiade: «I encara una alura cosa: l'expressio d'idees noves, típiques de l'actitud caracteristica de l'home del Renaixement $(1990,35)$. Es mas, no puede decirse que irrumpan como nuevos los temas de la Fortuna o la muerte; en realidad, difiere el tratamiento por encima de las temáticas. Asimismo, en los epigonos catalanes, se dan cosas tan curiosas como la reaparición de Llull (n. 64 infra), quien es sabido que no es precisamente un humanista pero quien -quizds por su postura al margen del escolasticismo - abona una corriente en el Renacimiento (Vilallonga 2001, 488; Batllori 1995, 52-54). 
o período deberá delimitarse dentro de un marco temporal caracterizado por rasgos literarios - temáticos y formales - que se manifiestan en obras, autores, generaciones, escuelas, y que los contienen en fases de gestación, madurez o decadencia, pero distinguibles de aquellos que se encuentran en los perodos vecinoss. ${ }^{39}$

Vamos a iniciar el comentario a esta larga cita desde el terreno particular, pues el primer párrafo puede dar razón de por que hasta ahora no había divagado en torno a problemas teóricos frente a una polémica abierta, o sea que me he limitado al estudio de los textos, sin entrar en la dialéctica. Sencillamente, me he dedicado a estudiar las cualidades de un vino más que su conflictiva o prestigiada etiqueta ${ }^{40} ; 0$ sea, me he ocupado más de obras individualizadas que de caracteres abstractos ${ }^{4}$. He aquí el inicio de mi estudio metgiano, en que teorizaba mínimamente: «Este libro continúa la serie de estudios iniciada con Tras los origenes del Humanismo: El Curial e Gikelfa, que trata de estos orígenes en las letras catalanas. Seguimos aquí, de acuerdo con la línea comenzada, remontando hacia el pasado y según el concepto de Humanismo que en aquella Introducción expresáramos. Es decir, entendiendo éste como un fenómeno cultural y estético, valorador de la razón humana, con raíces en la Antiguiedad clásica, y que se manifiesta en obras filosóficas, artísticas y literarias ${ }^{42}$. Como movimiento que recupera una actitud es un fenómeno recurrente, si bien es el originado en el siglo XIV el que por antonomasia reconocemos hoy bajo el concepto de rescate de los clásicos, quienes constituyen en realidad el primer y auténtico Humanismo.

Esta concepción del movimiento es acorde con los planteamientos del profesor Batllori, quien lo concibe como una actitud que marca el paso del hombre hacia la modernidad ${ }^{43}$, sin pretender concepciones dicotómicas y recordando a la

${ }^{30}$ Las obras referidas se han recogido en nuestra bibliografia.

$40 \mathrm{Es}$, pues, lo que reclamaban los mantenedores del no-Humanismo catalán como valor sustantivo; asf, L. Badia $(1980,68)$, quien concluye: $\star B s$ tracta, en síntesi, de donar més valor als fets que no pas al muntatge historiografic que hom pot bastir a partir d'aquests fets» (ib., 70). Mal uso del que ya nos habia alertado un gran acuñador del concepto, J. Rubi6: *Hemos de tener siempre en cuenta el valor convencional de etiquetar con un nombre cualquier perfodo de la historia de la cultura» $(1990,167)$.

4! Un segundo intento de análisis desde una posición teórica es mi ultimo trabajo, Algunas consideraciones sobre Poética medieval en el Humanismo Cataldn: Bernat Metge y el *Curial e Glelfa*, *Revista de Poetica Medieval», en prensa.

12 Según este intento de definición destaca el papel de san Agustín, como afirma el profesor Agustín Uña en La modernidad del siglo XIV (1993). En cuanto a la proximidad del bagaje clasicista gracias a su recuperación, cabe recondar que kel trecho mayor del camino hacia los clásicos ha de discurrir a traves de sus recreaciones, adaptaciones, resonancias en la literatura...* (F. Rico, del texto lef́do tras la entrega del premio «Promotor de los Estudios Latinos", cit. del "Boletín Informativo de la Sociedad de Estudios Latinos" 20,2003, 27); es decir, que los humanistas nos transmiten aquel legado desde un posicionamiento más cercano.

43 kEntenem, per tant, els termes Humanisme i Renaixement no com un perfode cronolögicament parlant, ans com una actitud comuna de pensadors que, des del final del segle XIV fins al final del XVI, en tots els camps de l'especulació intel-lectual assumeixen posicions en sintonia amb la mutacio de l'home caracteristica del pas de l'Edat Mitjana al món modern" (Batllori 1995, 29); si bien tampoco identifica modernidad y Humanismo, como distingue E. Duran (Els estudis sobre el Renaixement, Institut d'Es- 
vez que Humanismo y Renacimiento no son sólo Filología. Según este historiador es tema que interesa hoy a los investigadores europeos» $(2002 \mathrm{a}, 11)$.

El párrafo final del profesor Gutiérrez Carbajo, por otro lado, incluye aspectos que había tenido en cuenta en mis monografías, especialmente en lo relativo a la imposibilidad de pretender obras pristinas y al entrecruzamiento de sombras, matices e influjos de distintas procedencias, lo que está especialmente claro en el caso del Curial, que llega a ser un caso paradigmático de hibridismo (Butiñá 2001, 344-347) ${ }^{44}$. Así como, también a su luz, se impone la metodologfa comparatista para las obras con atisbos de Humanismo. En la obra de Metge, además, se hacen palpables rasgos que luego serán de indiscutible signo humanista, como sujetar la filosofía a la elocuencia - cosa que más tarde asentará un Lorenzo Valla (Rico 1993, 88-89) - , establecer la guía de la gentilidad - que será característica de Luis Vives - o el aferrarse a la filosofía platónica del amor - rasgo muy significativo entonces, incluso respecto a Italia - . $^{45}$

En resumen, si el trabajo del profesor González Rolán efectúa una tarea de definición y ordenación, sumamente aclaratoria desde la perspectiva conceptual, el de Gutiérrez Carbajo es esclarecedor sobre todo desde la diacronía y la teorfa. Ambos - habiendo asumido concepciones que, como la de Curtius, han supuesto un gran avance - evidencian la importancia del Humanismo para la cultura occidental y son útiles para resituar enfoques parciales de aquel movimiento en un encuadre general, puesto que sus postulados ofrecen un nuevo cauce apto para ser asumido en amplitud ${ }^{46}$; por ello, habla que ponerlos en conexión con el Humanismo catalán, máxime cuando - según dijimos ya - sus supuestos dan sustento a la línea tradicional de estos estudios.

En el segundo libro, se apalancan posiciones propias de la literatura, las derivadas - aunque no en exclusividad - de los estudios literarios. Así como se evidencia lo innecesario de ser tajante en las delimitaciones, frente a la conve-

tudis Catalans. Secció Historico-arqueoldgica, Jornades sobre l'obra de Miquel Batllori, Barcelona 1997, 46). Entre otros pareceres proximos, cabe situar el de Giovanni Di Napoli, quien se fundamenta en estudios de Gentile y otros $(1963,10,12)$.

4 Gira sobre esa reflexión el capitulo A modo de conclusiones (335-358), ya que el hibridismo es lo que mejor define a esta obra, que sin una lectura humanista es enigmática e inexplicable. También serfan extrafias la Celestina u otras piezas literarias -encabezadas por la Divina Comedia- si no se leyeran sintonizando con su autor. Esto último no es una quimera, pues ahf están hechos como las fuentes; es decir, la genesis literaria, que hay que estudiar junto a la estructural o compositiva. Pero ello no supone adjudicar una intencionalidad -como suele hacerse con Metge-, pues esta forma parte de una sola genesis - la material - y es un campo mucho mas arriesgado y presto a ser predeterminado. (En mi libro del Curial armonizan, por este orden, los tres tipos de genesis: literaria, estructural y material).

45 VEase el texto metgiano correspondiente en la edición y traducción de Riquer, 346-349; he tratado del mismo en Bermat Metge, defensor de la dona i l'ideal de la pau, $\times$ Revista de Filologia Romanicaw XX (2003), 25-40.

46 En mi reseffa al libro de González Rolán... 2002 («Epos» XVIII, 2002, 523-535), insisto en que, a pesar de su constatación acerca de cuánto nos falta por conocer afin del panorama humanista hispániCo, su afín por cubrir lagunas y progresar en aquel conocimiento puede tener un efecto muy positivo, pues nos brinda una ocasión para lograr algo dificil de conseguir: sencillamente, un agora para dialogar. 
niencia de articular, especialmente por medio de las obras que hacen de engarce, o sea las de los momentos de transición ${ }^{47}$. En esta línea, incluso me he referido al Humanismo - tan de tránsito - como aquello que no es renacentista pero tampoco medievalizante. Por lo tanto, es un movimiento cuya idiosincrasia, de carácter mixto -entre la tradición y la innovación - , no permite medirlo a peso ni calibrando hacia qué lado se decanta, puesto que siempre oscila ${ }^{48}$. En las literaturas no italianas se define sobre todo por esa misma indefinicion - propia de cualquier proceso de cambio - , pues siempre era incompleta la renovación; pero son fallos que ya detectaba Metge en la cúspide del prestigio petrarquesco.

Ello no quiere decir que todos los autores que presenten esa mixtura deban considerarse humanistas, pues no todos se manifiestan favorables al cambio y a la modernidad: asi, no lo son ni Fernández de Heredia, a pesar de traducir obras griegas, como tampoco Turmeda ni Eiximenis, a pesar de lucir una moral desprejudiciada y un espiritu contestatario e individualista - uno- o un nuevo sentido social de la gestión económica y el lucro -el otro (Uña 1995)-, pues no arraigan en la ética y estética clasicistas.

Sin embargo, abren un precioso abanico los perfiles de las figuras ambivalentes, que titubean entre lo innovador formal y lo anticuado ideologico, como ocurre con un Roís de Corella - más renacentista que humanista -, para quien una bella escena de voyeurismo sirve de terapética moral, o el dominico Canals, que alertaba de virtudes paganas como el suicidio. Pero da altamente positivo el Curial, que se complace gratuitamente en la descripción de un beso largo y sensual, con el envés de los labios; o donde al héroe no le convierte un agrio sermón boeciano sino el dios Baco, o bien la heroína en amor se quita la vida emulando a Dido; así como también Metge, que en las cartas de su Griselda rescata la referencia heroica a una suicida que la senil de Petrarca había esquivado (n. 54 infra) y quien en Lo somni otorga categoŕa profética a Ovidio. De hecho, todos ellos nos acercan a los clásicos.

Todo esto no es cuestión baladí, pues para asimilar bien una cultura es preciso exprimirla como un limón, cosa que -y vuelvo a mi pequefío punto de mira - puede estar aún muy por hacer en la literatura catalana cuando se hace tan difícil entenderla o engarzarla desde aquel primer momento y especialmen-

47 J. Rubí comenta que en Catalufia se dio una falta de flexibilidad hacia la corriente renacentista y que la aristocracia intelectual perdió el sentido de las voces del pasado $(1990,138,91)$, y estimula incluso a buscar los precedentes desconocidos de las canciones populares ( $*$ Tot esta a trobar les anelles de la tradició, ib. 142). Recientemente, Marfany ha intentado reestructurar otra tpoca de transito, la referente a los orfigenes de la Renaixença; destaco que acude tambien a J. Rubió para un panorama vasto de historia literaria, que no excluye el enfoque cultural y que su planteamiento le lleva a explicarse cosas que antes resultaban inexplicables (Marfany 2003, 655). Advierte esto asimismo con obras concretas; y en la epoca que tratamos, por ejemplo, acabamos de observar que el Curial, sin una lectura humanista, resulta una obra oscura e incomprensible de un autor estrambotico.

4 Al ver que el Curial, por ejemplo, conjuga elementos próximos a las crónicas y a la narrativa artúrica, además de transportar a autores clásicos y, sobre todo, a los trecentistas, se constata su función de bisagra. 
te con la etapa siguiente. A mi entender, el signo humanista fue incomprendido - ya - por los autores inmediatos; del Tirant se dejo de hablar prácticamente - aunque tuvo mejor suerte con Cervantes - y Ovidio como profeta se consideró un error - esto hasta nuestros días - .

Es decir, no hubo rechazo pero tampoco evolución, como suele ocurrir en las distintas etapas de la historia literaria: sencillamente se olvid $\sigma^{49}$, fallando la asunción del propio legado; o sea, de los autores que mejor habran escrito y transportado - junto con el clasicismo- un muy alto bagaje. Ahora bien, esa inconexión ${ }^{30}$ no elimina sino que, al contrario, ratifica la necesidad de aquel reconocimiento (en clave de reconstrucción, no de construcción) como parte constitutiva de una tradición."

Evidentemente no actúan sobre una cultura los elementos que no han influido - y asf dijimos que ha ocurrido con Metge -; sin embargo, si se dieron en su historia cultural, no deben perderse pues pueden cobrar nueva vida y ser regeneradores del propio tejido. El cual se forma en el pasado y no se puede modificar, pero tiene vigencia en la medida en que se reconoce y cobra entidad; y sólo en la medida en que está vivo es útil. He ahí el interés de los humanistas por apropiarse, rescatar, hacer revivir la Antigüedad.

Se suele ver entre los factores de la interrupción -dado que el énfasis humanista catalanoaragonés quedo truncado, pues la cultura renacentista serfa foránea (n. 23 supra) - el descenso en calidad de la producción literaria en los siglos posteriores; pero, veamos, ¿interrupción de qué?: ¿de unos autores que hoy apenas se leen ni se entienden, o de los que no escribían en su lengua?, ¿de unas obras maravillosas, fruto de mentes extravagantes o inmorales y casi delincuentes? Por otro lado, es impropio que una tradición cultural se base tan contundentemente en una negación, como ocurre desde el no-Humanismo, que además ofrece un conjunto descoyuntado. Cabe preguntarse, pues, si la falta de vertebración procede de la misma incomprensión, que imposibilita una lectura

49 Salvo la producción ausiasmarquiana, prícticamente se dejo de lado el primer Humanismo; lo apunto también en mi resefla a: Prancesco Petrarca, Canfoner. Tria de sonets (trad. de Miquel Desclot, introd. de Rossend Arqué, ed. Proa, Barcelona 2003) en «Revista de Filología Italiana», en prensa.

so Despues de haber defendido este vocablo al profesor Josep Ysern - quien tuvo la amabilidad de leerse este trabajo y discutirlo previamente-, frente a «desconexion*, encuentro la siguiente frase en J. Rubio 1985, 9: «Tant l'esterilitat, o si voleu l'estancament, de la produccí́ literària en llengua materna a Catalunya com la florida de les lletres castellanes a Valencia, revelen un fet dolorós perd molt important: la inconnexió de la tradicio literaria en catala amb les tendencies de les seleccions creadores.*

of Se entiende, sin embargo, que no podría articularse la historia literaria catalana prescindiendo de Llull, independientemente de las modalidades o influencia que haya ejercido en las distintas epocas y temáticas. (Una reflexión desde Llull y hacia la modernidad puede verse en mi trabajo Un llibre catald, un gentil italid i la cultura europea, en Momenti di cultura catalana in un millennio, actas del VII Congreso Internazionale di Studi, Nápoles mayo 2000, editadas a cargo de A. M. Compagna, A. de Benedetto y N. Puigdevall, «Romanica Neapolitana» 31, dir. por A. Varvaro, ed. Liguori, Napoles 2003, vol. I, 72-74). 
natural de aquellas obras; en cuyo caso, la recuperación no será un hecho puntual ni obra de un individuo aislado.

Por ello, no habria que ver tanto aquella real y tremenda bajada como una manifestación decadente a explicarse -es decir, no se trataría tanto de andar a la pesquisa de causas y explicaciones de la decadencia - sino de verla como una lógica consecuencia; entonces no se trataría tanto de una literatura invertebrada - como suele aparecer - sino más bien pendiente de vertebrarse adecuadamente, de modo que esa línea quebrada y no modulada, antes y ahora, serfa más bien un efecto 6 ptico. ${ }^{52}$

Son cosas distintas: la falta de articulación no tiene obligatoriamente que deberse - 0 al menos quizás no haya que achacarla tanto- a los rasgos de la producción literaria en los siglos posteriores. Al fin y al cabo no hubo un abandono literario, sino que se siguió el ritmo marcado por otra literatura - ahora principalmente la castellana en vez de la italiana -; pero que las culturas se identifiquen más con unas u otras, según las olas de influencia, modas y momentos, no es nada insolito. Sí que se dio un gran contraste cualitativo, precisamente porque el momento humanista anterior, a la sombra directa de los trecentistas, fue álgido; por lo cual - bajo cualquier propuesta de estudio - aquel tiene que ejercer su función en plenitud..$^{33}$

La inarticulación puede atribuirse, simplemente, a que haya sido difícil entenderlo. Pero, si se me permite una imagen fácil, cuando en un engranaje falla un mecanismo, indudablemente se recobrará mejor el juego intentando atornillarlo o engrasarlo que eliminándolo. Esto último sucede al deducir que, por raro y extraordinario (n. 9 supra), no ha podido llegar a darse; recordemos a proposito la carta final del Griselda de Metge, sobre la discusión petrarquesca ya aludida: «axí fo allà com dessús és dit, jatssia que alguns menyscreents e viciosos diguen que impossibla és que dona del món pogués haver la pasciència e constancia que de Griselda és scrita»..$^{34}$

52 Pongo un ejemplo practico con el Tirant, cuya armazón interna desconocemos afin. Wittlin (2002, 54), tras haber analizado el procedimiento de Martorell con la Letra de reials costums de Petranca, opina que estamos lejos de explicarlo y que, dada su peculiaridad, es un caso único *i potser aberrantr. Es decir, o hay, por nuestra parte, incapacidad de una vista de conjunto de la obra o bien ésta carece del equilibrio y composición armónica de otras obras humanistas; en tal caso, sólo habría asimilado unas técnicas - no sus construcciones - y se asemejaria a los frutos de un tardío renacentismo. Mayor optimismo parece mostrar J. Ysern en Introducción a las Lenguas y Literaturas Catalana, Gallega y Vasca, UNED, Madrid 2004, 152.

53 Alguna historia de la literatura incluye este movimiento normalmente; asf tambien, los libros de docencia de la UNED, que coordino, incluyen el Humanismo con relieve en la Edad Media (Literatura Catalana, I); desde el siglo XVI, se puede seguir el proceso cultural gracias a los trazos de August Bover (II, 113-199) y, en la introducción al volumen III, (9-15),correspondiente al siglo XX, se ofrece un intento de esbozo general, coherente y retrospectivo.

34 Sigue: «Als quals hom poria ben respondre que ells tenen aquella oppini6 per ço com ymaginen que asso qui a ells 68 difficil sia als altres impossibla. Car moltas donas son stades qui han hallda meravellosa pasciéncia, constància e amor conjugal, axí com fo Pòrcia, filla de Cato, qui-s mata com sabe que Varro, marit seu, era mort» (Riquer 1959, 154). 
Y si la falta de juego articulatorio se debe al hecho de prescindir del movimiento que hace de quicio, es lógico que resulte imposible seguir el curso de esta literatura, donde aquél ha sido tan importante y recogía ya en su seno la propia tradición luliana. Por ello decíamos que hasta tal punto consideramos que fue trascendente en la Corona catalanoaragonesa que su proceso cultural sólo se explica entendiendo - con normalidad, como en otras literaturas - aquel paso de la Edad Media al Renacimiento. Pues se dio con gran intensidad y elevación, aun siendo muy de minorfas y restringiéndose prácticamente a un siglo; incluso por su fugacidad concuerda con el Humanismo en general, que se ha concebido como un sueño (Rico 2002 a).

Mientras que, extirpándolo, hallamos una literatura carente de movimientos antes del Romanticismo - es decir, se estudia de modo plano, del siglo XIII al Barroco, y sin enlazar apenas con el mundo exterior-, lo cual hace inexplicables los textos desde la concepción histórico-literaria, que pretende concatenar hechos y comprender los rasgos predominantes y cambiantes, aun asumiendo desconocimientos y olvidos.

Por otro lado, la incomprensión de aquella aportación se está prolongando en la medida en que perdura su marginación. Un curso literario -insisto, aun empleando supuestos teóricos - no es inarticulado por presentar altibajos, que todas las literaturas experimentan en mayor o menor medida; mientras que parece imprescindible el conocimiento de la propia identidad y de sus relaciones, en la dosis más plural posible, a fin de su seguimiento. Y lo es en las dos direcciones, tanto para seguir sus pasos históricos como para permitir posibilidades de recuperación: desconocer o negar la existencia de algo aborta su crecimiento o desarrollo, dado que esa posibilidad queda anulada. En lo cultural ocurre, como en todo ser vivo, que cuanto más constitutivo es un rasgo - sea la pertenencia a un linaje, sea el arraigo a una lengua o expresión -, más necesario se hace el reconocerlo. No en vano el Humanismo es el movimiento que ensalza la dignitas hominis.

Desde el ángulo linguístico, partiendo de un siglo XIX con una conciencia acongojada de la situación, se ha llegado a asumir en el XX conceptos como la normalización; ahora bien, en el cultural estamos lejos de una conciencia acongojada. Pero la lengua, al fin y al cabo, vehicula y es soporte de una cultura: he ahí -entre las muertas - las clásicas, pletóricas de vida cultural y constituyentes de una rica tradición.

Antes de hacer algunas propuestas finales, paso a abrir unas reflexiones: ¿Por qué no contemplar el Humanismo catalán -en su justa medida, pero de pie, sin complejos de superioridad ni inferioridad - como se hace con el castellano, el francés, etc.? Ello no supone ningún tipo de idealización falseadora de la realidad, pues no se trata de recomponer forzadamente ninguna línea triunfal ascendente, que no se ha dado en nuestra cultura cuando tanto tiene que volver sus ojos a la Edad Media. Pero tampoco hay ningún dictamen que marque topes o señale una anhelada continuidad, ni mucho menos hay lecturas univocas, así como parecen dudosas cientificamente hablando las excluyentes. Una vez más, no caben los extremos: no hay que magnificar las notas de ningún momento, pero tampoco repudiarlas. Basta estudiar los fenómenos en su contexto: el 
Humanismo catalán dentro del Humanismo hispánicoss; y ambos en relación con el italiano, dentro del conjunto europeo.

¿Cómo hubiera sido - si se hubiera llegado a dar - la generación del 27, en la literatura española, de no haberse valorado debidamente el Siglo de Oro?, 20 cómo sería la francesa sin haber absorbido a fondo un Montaigne o la italiana sin entenderse la Divina Comedia? Evidentemente, estas literaturas no sólo perderfan en cohesión sino que serfian menos ricas, pues el reconocimiento de la tradición genera posibilidades de nuevas vivencias.

No hay que augurar que de una recuperación concreta se vayan a derivar renacimientos. Pero observemos los efectos contrarios: cuando un gran autor como Jacinto Verdaguer quiere remontarse a los orígenes de su literatura, en el momento decimonónico de renacer, y volver a la propia identidad, no cae, como la mayoría, en el pasado provenzal y trovadoresco; gracias a su cultura, lo supera y encuentra sus fuentes de inspiración en el acervo más genuino, además de Llull, el legendario y popular (Canig6), el clásico y el hispánico (Atlántida). Ahora bien, un autor de tan fina formación clasicista no utilizaba gran parte del propio caudal clasicizante (Metge, Martorell, el Curial, Corella...); y este desconocimiento pudo serle una merma ${ }^{\text {s6 }}$, porque el no conocer las rarces es algo que estrecha el cauce cultural y no permite beber en amplitud de su acervo.

Tambien desconocieron en parte aquel pasado Carner y los noucentistas, precisamente quienes intentaron una vuelta al clasicismo a principios del siglo $\mathrm{XX}^{37}$, lo cual no disminuye su merito sino que lo aumenta. Pues así como Metge en un diálogo profundo se referfa a Llull -a quien, junto con los clásicos y sin obstáculo, hacía suyo ${ }^{58}$ - los dos autores modernos citados - Verdaguer y Carner - no pudieron remontarse a parcelas de su propio caudal que les pudieran haber sido válidas, bien porque no las tenían a su alcance, bien porque no contaban con estudios filologicos que las vivificaran suficientemente. Cabe repasar las obras importantes de aquella epoca medieval que hasta prácticamente el siglo XX no se han descubierto, como el Curial, o que apenas se han estudiado hasta los últimos decenios, como las de Roig, Corella e Isabel de Villena. ${ }^{59}$

ss $O$ iberico, segun el enfoque batlloriano (Batllori 1995, 27-108, 119-132).

so Esta idea la apunté en un trabajo que hice con ocasión del centenario de su muerte: Trazas comparatistas sobre Vendaguer, kLiceus. Revista de Humanidades» I/2 (2002), 60-65, n. 17.

7 Recientemente he enfrentado a Camer como humanista con Metge, pero, a pesar de la tendencia clasicista del primero y de tratarse de la misma literatura, distan tanto que extraña fuertemente ni siquiera ponedos en contacto (vease Una nova font de «Lo somniw de Bernat Metge: Horaci, en Memdria, escriptura, historia: Professor Jonquim Molas, *Homenatgesw, I, Universidad de Barcelona 2003, 230).

su Deade 1994 trabajo sobre la influencia lulista en Metge, apuntada por A. Rubio en 1917 (vease Unes notes sobre Metge, Lull $i$ Juvenal, en Homenatge a Miquel Batllori, 4, «Randaw 51, 2003, 7-29).

59 Por ello, la dormición secular en estudios, bastante general en nuestras latitudes, es tanto o mas grave que la que se da en la vertiente de cultivo literario. Pues el distanciamiento puede deparar algo parecido a lo que pasaba en la Edad Media con los autores clasicos, que se veneraban repetitivamente pero no se entendfan. Por ello también, a pesar de que se bauticen prestigiadas instituciones con nombres de autores y obras del pasado, lo que interesa verdaderamente es saber - trabajar entre todos para 
Esto está en la diáspora de contribuir a ningún ismo empobrecedor ni empequeñecedor ${ }^{60}$, pues, al contrario, lo que se está proponiendo es conocer mejor el momento clasicista, a fin de conectar con otros bagajes y así sucesivamente. Este engarce y reconocimiento es uno de los móviles para el estudio de cualquier Literatura.

Los expertos en teorizar añaden causas de lo inconexo y decadente en el Quinientos, entre las que no pueden olvidarse hechos como la bajada demografica, que ya mostró Vicens Vives: la peste negra diezmó la población con la consiguiente repercusión en la clase patricia - es decir, la culta o con inquietudes intelectuales -, mientras que el pueblo siguio manteniendo la lengua y sus manifestaciones líricas y dramáticas. Son hechos que explican la reducción del cultivo literario y a la vez el firme arraigo cultural. ${ }^{2} \mathrm{Y}$ aquí, desde el plano tan actual de la audiencia, cabe abrir aún otra reflexión: ¿quién entendio Lo somni al margen de la breve incursión de un humanista como Ferran Valentr, traductor de las Paradoxa ciceronianas, en cuyo prólogo se muestra perspicaz diagnosticador de las imitaciones de Metge y valorador de la propia historia literaria ? $^{3}$

Además de haberse desconocido secularmente buena parte de las rafces culturales, quizás no ha habido tiempo para una asimilación de todas las piezas, dado que falta mucho aún por recomponer, en documentos, relaciones, etc., que aclaren mejor los hechos. La literatura saca su fuerza quizás principal de la misma literatura y nos falta comprensión del perfodo clásico de estas letras, así como repasos y vueltas a Llull; tanto por él mismo como por hallarse detrás de los origenes humanistas ${ }^{64}$.

En cualquier caso, el hecho de la dispersión de pareceres - como se da en la actualidad - no debería ser negativo, sino estimulante para las investigaciones.

saber- por qué son excelsos, en toda su dimensión, y por qué los han valorado las grandes personalidades. Urge, pues, revisar nuestros estudios y nuestros revisionismos, porque, al igual que no hay que adocuar los textos a unas expectativas, hay que evitar el criterio reverencial al que de otro modo pudiera llegarse.

60 Decia J. Torras i Bages en La tradicio catalana (1892) que «El Regionalisme i el Renaixement son antitetics" (ed. Selecta, Barcelona, $3^{2}$ ed. 1966, 349).

61 Los humanistas pretendian algo semejante respecto a fndices modelicos para todos los hombres; baste recordar su entusiasmo por recuperar los códices del pasado y la repercusión que éstos ejercian. Sin unos precedentes no se dan otras obras (Rico 1993, 157-159), pues ya es sabido que, según el principio formalista, las obras se crean en referencia a un modelo (Gutierrez Carbajo 2002, 33).

Q2 Barcelona, en la época de Carlos V, contaba con unos 35.000 habitantes, pero aun ante ese reducto, considera J. Rubio que, aunque no se encuentren obras magistrales, hay una trama vital cohesionada y advierte que ese ambiente literario no fue tan débil como para justificar la debilidad de su producción: «Deixant de banda causes polítiques, no en trobariem tambe alguna de literaria?», 1990, 120.

63 Hay que recordar que se dio en paralelo y proximo al Prohemio de Santillana (Riquer 1964, 466).

- Cabe considerar dos cosas: la ascendencias para con Metge y, por otro lado, las curiosas vias de influencia Sibiuda-Montaigne-Loyola, que ha estudiado Batllori (1990), o bien la que deriva hacia Cisneros. 
Pero, para seguir andando ${ }^{65}$, parece imprescindible utilizar el término Humanismo aplicado a la Corona catalanoaragonesa ${ }^{66}$, frente y junto a -es decir, en lo que se oponen y en lo que tienen en común - la literatura de la Corona de Castilla. Con sus tres etapas y ciudades, en torno a las cuales se dibujan estos rasgos ${ }^{67}$. Y con flexibilidad terminologica, hasta que se fijen índices de referencia más generales y concretos, a fin de facilitar el entendimiento del fenómeno en toda su amplitud ${ }^{68}$, así como con receptividad ante periodizaciones que provengan de síntesis que procuren marcos comunes. A ello responden -en cuanto a los oscuros origenes del importante movimiento que precede a la modernidad y está en la génesis de los renacimientos artísticos y de la ciencia (Debus 1996, 16, 239, 254 passim) - las espléndidas aportaciones de los dos profesores con los que hemos relacionado la literatura catalana.

Es de esperar que, de este modo, a la par que los conocimientos, quizás vaya calando un nuevo talante, de apertura y soltura, más acorde con nuestros tiempos; ya que, de hecho, siempre imperan las modas. En el Curial, en un inciso alegorico que rompe el realismo dominante, se nos describe una Fortuna pomposa, de alto empaque, en medio de un brillante escenario mitológico, entonces tan en boga:

«yo són aquella Fortuna de la qual les gents tant parlen» (III, 223, 6-7).

El autor la retrata en ese último libro como una diosa a la moda, pero lo hace con cierto deje burlesco, como una figura ilógica, ridícula y huera; sin embargo, desde el prólogo estaba presente el infortunio, que, como tema filosófico tan preocupante en todos los tiempos, recorre con sus inherentes implicaciones morales subterráneamente toda la novela ${ }^{69}$. Este fino humanista, dis-

6s Especialmente al no haber en la actualidad controversia que sirva de orientación; falta de polemica que es un rasgo más a denotar que nos hallamos en las antipodas de las actitudes humanistas, esencialmente abiertas y dialogadoras.

o6 Las ideas que he ido hilvanando comulgan con la opinión tradicional literaria catalana, que, de innegable ascendencia luliana, pasa por el Humanismo; y sobre todo - perfilo- por Metge.

67 La ordenación en tomo al comienzo de tres reinados procede de A. Rubio y es la que sigue Batllori (1995, 45-46). Centrándome en la creación literaria, en un seminario sobre Historia y poética de la ciudad en la Península Ibérica (Butińá 2002 c), dibuje esos tres momentos sobre los núcleos urbanos que la aglutinan (Barcelona, Nápoles y Valencia), los cuales coinciden prócticamente con aquella división.

* Recientemente ( $\alpha \mathrm{El}$ Pafs», 14 noviembre 2003, 39), Rico considera que "La idea de la literatura del humanismo era la poesfa pura, y la historia de la literatura ha ido en contra de eso. La realidad contra la literatura." Si, según hemos contemplado aquí, el Humanismo filologico no se restringe al petrarquesco, advertimos un movimiento, realista y válido, que puede verse esculpido en la fórmula con que el autor del Curial, a traves de Apolo, pronuncia su juicio literario: "contra veritat escriure, no'm par sie loor" (ed. cit., III 89). Ideal que alcanza desde el Decamerón y Lo somni al Trant y al Quijote o a las obras más actuales.

69. Este personaje alegórico, que estudie en las letras catalanas (El paso de «Fortuna» por la Peninsula durante la baja Edad Media, «Medievalismo. Boletín de la Sociedad Espanola de Estudios medievales» III, 1993, 209-232), es uno de los conceptos claves que denotan el cambio ideológico, según opinaba ya Eloy Benito Ruano al encomendarme aquel trabajo (la ha estudiado más recientemente, como relevante en el genero de la novela caballeresca, J. M. Manzanaro: Fortuna en el «Tirant lo Blanch* $i$ en el «Curial e Guelfa», Universidad de Alicante 1998). Respecto a otros trabajos, en los que compare la 
tinguía así lo pasajero de lo estable, al igual que sabía expresar liviana y placenteramente ideas tan graves como el precepto délfico y la brevedad temporal:

"Yo.t prech, Curial, que torns en tu mateix, e regoneix-te bé mentre has temps» (II 293, 14).

\section{REFERENCIAS BIBLIOGRÁFICAS}

Aguiar e Silva, V. M., Teorla de la literatura, ed. Gredos, Madrid 1979.

Alemany Ferrer, R., Guia bibliografica de la Literatura Catalana medieval, «Biblioteca de Filología Catalana» 1, Universidad de Alicante 19972.

AMORós, A., Introducción a la literatura, Castalia, Madrid 1979.

Aramon i Serra, R. (ed.), Curial e Gulelfa, I-III, «Els Nostres Clàssics», ed. Barcino, Barcelona 1930-33. (Hay traducción de P. Gimferrer, ed. Alfaguara, Madrid 1982), y de J. Butiná en www.ivitra.ua.es

BADIA, L., El terme «Humanisme» no defineix la cultura literaria dels nostres escriptors en vulgar dels segles XIV $i$ XV, «L'Âvenç» 200 (1996), 20-23.

tD., De Bernat Metge a Rots de Corella, ed. Quaderns Crema, Barcelona 1988.

fD., L' 'Humanisme catald»: formació $i$ crisi d'un concepte historiogrdfic, en Actes del Cinquè Col-loqui Internacional de Llengua i Literatura Catalanes. Andorra, 16 d'octubre de 1979, Publicaciones de la Abadfa de Montserrat 1980, 41-70.

BADIA I MARGaRT, A. M., La impronta renacentista en las letras catalanas. Latin y romance en los siglos XV y XVI, «Revista de Lenguas y Literaturas Catalana, Gallega y Vasca» 4, UNED (1996), 165-180.

BATLLORI, M., Obra completa, V, De l'Humanisme i del Renaixement, pról. de E. Duran, ed. Tres i Quatre, Valencia 1995.

tD., En los inicios de la plena Edad Moderna: Sebond, Loyola, Montaigne, en Temas de varia historia, «Suplementos. Anthropos» 23 (1990), 54-60.

BATTISTI, E., L'antirinascimento, ed. Feltrinelli, Milán 1962.

BOVER, A., La época del Renacimiento y el Manierismo, La época del Barroco, El siglo XVIII: Barroco, Rococo e Iluminismo, Los inicios del siglo XIX: el Romanticismo y el proceso hacia la Renaixenfa, en Literatura Catalana, II, Siglos XVI-XIX, UNED, Madrid 1998, 113-175.

BRANCA, V., Boccaccio medievale e nuovi studi sul Decameron, ed. Sansoni, Florencia $1992^{8}$.

Fortuna del Curial con la de Santillana (Butifia 1993 a) y con la de Mena (Butifia 1992), recalcarfa ahora como el contraste entre ambas literaturas - por encima de los motivos politicos, que resaltaba entonces incluso en el tútulo del trabajo sobre el segundo autor - se debe a los distintos matices del Humanismo que sus autores estaban respirando. 
Brown, P., El mundo en la Antiguledad tandía, ed. Taurus, Madrid 1991.

BUTINÁ, J., La recepción del Humanismo (del siglo XIV al XV); Bernat Metge: el diálogo de "Lo somni», La primera novela caballeresca: el «Curial e Glielfa», en www.Liceus,com.

ID., La font més amagada i més externa de «Lo somni»: un altre somni, «Estudis Romànics» XXV (2003 a), 239-251.

fD., Un nou «Libre de Fortuna e Prudencia», «Revista de Lenguas y Literaturas Catalana, Gallega y Vasca» 8 (2003 b), 27-62.

fD., En los origenes del Humanismo: Bernat Metge, UNED, Madrid 2002 a.

fD., Del Griselda catald al castelld, «Minor» 7, Real Academia de Buenas Letras de Barcelona, 2002 b.

ID., Barcelona, Nápoles y Valencia: tres momentos del Humanismo en la Corona de Aragón, en Historia y poética de la ciudad. Estudio sobre las ciudades de la Pentnsula Ibérica, «Revista de Filología Románica» III/2002 c, coord. por E. Popeanga y B. Fraticelli, 81-98.

ID., Tras los origenes del Humanismo: El «Curial e Guelfa», UNED, Madrid 2001 ${ }^{3}$.

fD. (coord.), Literatura Catalana, I-III, UNED, Madrid 1997-1999. (Véanse también los cuadernos www.uned.es/453196, donde pueden consultarse mis tres monografías).

ID., La conciencia linguitstica en las letras catalanas de la Edad Media: del campo histórico y del filosofico a la ficción, en Emma Martinell y Mar Cruz (eds.): La conciencia lingultstica en Europa. Testimonios de situaciones de convivencia de lenguas (ss. XII-XVIII), PPU Barcelona 1996, 79-134.

fD., El diálogo de Bernat Metge con Ramon Llull. Dos nuevas fuentes tras *Lo Somnix, en Actas del V Congreso de la Asociación Hispánica de Literatura Medieval, Granada 1995 a, 429-444.

fD., Acerca del lulismo castellano, «A Distancia» otoño 1995 b, 51-54.

D., Metge, un bon lul.lista $i$ admirador de Sant Agusti, «Revista de Filologfa Románicas XI-XII (1994-95), 149-170.

ID., La «Comedieta de Ponça y el *Curial e Guelfa* frente a frente, *Revista de Filología Espańola» LXXII, Madrid 1993 a, 295-311.

fD., Convivencia de lenguas en «Curial e Guelfa $y$ *Tirant lo Blanch», «Boletín de la Real Academia de Buenas Letras de Barcelona» XIIII (1991-92), Barcelona 1993 b, 333-346.

fD., Juan de Mena $i$ el «Curialk: som davant un antagonisme polttic?, en Miscel.Lania Joan Fuster 5, Publicaciones de la Abadía de Montserrat 1992, 95-100.

Compagna, A. M., Lo spazio letterario del Medioevo. 2. Il Medioevo volgare, II, La circolazione del testo, ed. Salerno, Roma 2002, 595-620.

CouTINHo, A., Introduçâo d literatura no Brasil, Livraria Såo Jose, Río de Janeiro $1964^{2}$.

Cysarz, H., Los períodos en la ciencia literaria, en Filosofia de la ciencia literaria, Ermatinger et al., Fondo de Cultura Económica, México-Madrid-Buenos Aires 1984. 
DEBUS, A. G., El hombre y la naturaleza en el Renacimiento, Fondo de Cultura Económica, México 19962.

Dionigi, I., Di fronte ai classici, Biblioteca Universale Rizzoli, Milán 2002.

GARCIA CARCEL, R., Batllori y el Renacimiento español, en Miquel Batllori. Una historiografia puntual de la cultura occidental, «Anthropos. Revista de documentación científica de la cultura» 112 (1990), 51-53.

Gonzalez Rolán, T.; SAQUero, P., y LÓPEZ Fonseca, A., La tradición clásica en España (siglos XIII-XV). Bases conceptuales y bibliográficas, ed. Clásicas, Madrid 2002.

González Rolán, T.; Moreno Hernández, A., y SAQuero Suarez-Somonte, P., Humanismo y teorfa de la Traducción en Espanta e Italia en la primera mitad del siglo XV, ed. Clásicas, Madrid 2001.

Gonzalez Rolán, T., y Saquero, P., El Humanismo italiano en la Castilla del Cuatrocientos: estudio y edición de la versión castellana y del original latino del «e infelicitate principum» de Poggio Bracciolini, «Cuadernos de Filología Clásica. Estudios Latinos" 21, 115-150.

GutífrRez Carbajo, F., Movimientos y Epocas Literarias, UNED, Madrid 2002.

HAUf, A., Sobre els estudis de tema medieval del pare Miquel Batllori, S. I., en VV AA, 2001, 37-56.

Hermans, T., The Manipulation of Literature. Studies in Literature Translation, Londres 1985.

JABOER, W., «Paideia»: los ideales de la cultura griega, Fondo de Cultura Económica, Madrid $1985^{9}$.

KRAYE, J., Introducción al humanismo renacentista, trad. española a cargo de C. Clavera, Cambridge University Press, Madrid 1998.

MARFanY, J. L., En pro d'una revisió radical de la Renaixença, Memdria, escriptura, histdria, en Professor Joaquim Molas, «Homenatges», II, Universidad de Barcelona 2003, 635-656.

MARTINEZ ROMERO, T., Aproximacio als sermons de sant Vicent Ferrer, «Francesc Ferrer Pastor» 8, ed. Denes, Valencia 2002.

Metge, B., Obra completa de Bernat Metge, ed. a cargo de L. Badia y X. Lamuela - sigue la del Dr. Riquer de 1959-, ed. Selecta, Barcelona $1983^{3}$.

ID., Obras de Bernat Metge, ed., estudio y traducción a cargo de Martín de Riquer, Universidad de Barcelona 1959.

MORABITO, R., Griselda tra rexemplum» ed esempio, en I tratatti di saper vivere in Italia, dir. por A. Montandon, Centre de Recherches sur les Littératures Modernes et Contemporaines, Clermont Ferrand 1993, 25-43.

NADAL, J. M. y Prats, M., Histdria de la Llengua Catalana, I y II, ed. 62, Barcelona $1983^{2}$ y 1996.

OlezA, J., Sincronía y diacronía: la dialéctica del discurso poético, ed. Prometeo, Valencia 1976.

Pérez Priego, M. A., Boccaccio en la obra literaria de Santillana, en La recepción de Boccaccio en España, Cuadernos de Filologta Italiana. Actas del Seminario Internacional Complutense 18-20 de octubre de 2000, ed. por María Hernández Esteban, Madrid 2001, 479-495. 
PUIG I OLIVER, J. de, Humanisme catala?, «Arxiu de Textos Catalans Antics» X (1991), 292-297.

REBAGLIATO I FONT, J., La Hispdnia catalana. Evolucio histdrica dels elements nacionals catalans (segles XIII-XX), «La mata de jonc» 37, ed. Curial, Barcelona 1999.

RECIO, R., Petrarca traductor: los cambios de traducción peninsular en el siglo XV a través de la Historia de Valter e Griselda, en Essays on medieval translation in the Iberian Peninsula, coord. por T. Martínez Romero y Roxana Recio, «Estudis sobre la Traducció» 9, Universidad Jaume I, Castellón 2001, 291-308.

Rico, F., El sueño del humanismo. De Petrarca a Erasmo, «Biblioteca Francisco Rico», Colección Imago Mundi, ed. Destino, Barcelona 2002 a. (Es nueva edición, corregida y aumentada. Citamos también de la edición anterior: «Alianza Universidad» 754, Alianza Editorial, Madrid 1993).

fD., Estudios de literatura y otras cosas, «Biblioteca Francisco Rico», Colección Imago Mundi, ed. Destino, Barcelona 2002 b.

fD., Petrarca y el «Humanismo catalan», en Actes del sisè col-loqui internacional de Llengua i Literatura Catalanes, a cargo de Giuseppe Tavani y Jordi Pinell, Publicaciones de la Abadía de Montserrat 1983, 257-292.

RIQUER, M. DE, Histdria de la Literatura Catalana, II, ed. Ariel, Barcelona 1964.

RUBIÓ I BALAGUeR, J., Obres de Jordi Rubió i Balaguer, X, Estudis de Literatura Catalana, Publicaciones de la Abadía de Montserrat 1992.

tD., Obres de Jordi Rubio i Balaguer, VIII, Humanisme i Renaixement, Publicaciones de la Abadía de Montserrat 1990.

fD., Obres de Jordi Rubio i Balaguer, III, Història de la Literatura Catalana, II, Publicaciones de la Abadfa de Montserrat 1984.

UNA JUAREZ, A., Eiximenis, moral y moralidad en la gestión pública, «Cuadernos salmantinos de filosofia» XXII (1995), 51-68.

fD., La modernidad del siglo XIV, «La Ciudad de Dios» 206 (1993), 703-758.

Vv.AA., La saviesa de Batllori, ed. Sa6, Valencia 2001.

Vllallonga, M., Humanisme catald, en Miscel-lania d'Homenatge a Modest Prats, I, «Estudi General» 21 (2001), 475-488.

WelleK, R., y WARREN, A., Teorta literaria, ed. Gredos, Madrid 1974.

WITTLIN, C., L'antiga traducció catalana andnima de la «Letra de Reials costums» de Petrarca i el capitol 143 del «Tirant lo Blanc», en Miscel-lania Giuseppe Tavani, 3, Publicaciones de la Abadia de Montserrat 2002, 37-64. 